\title{
SPEECH ACT IMPERATIVE IN TEACHING ENGLISH ON PGSD STUDENTS
}

(Psycholinguistic Studies)

\author{
Dayu Retno Puspita ${ }^{1}$, Agus Sulaeman ${ }^{2}$ \\ University of Muhamadiyah Tangerang ${ }^{1,2}$ \\ dayuretnopuspita@umt.ac.id ${ }^{1}$, sultanwahyu13@gmail.com ${ }^{2}$
}

\begin{abstract}
This research analyzes Lecturer's Imperative Teaching in teaching English to PGSD students at Muhammadiyah University of Tangerang. Aspects analyzed include the form of speech acts and the meaning of speech acts imperative contained in teaching English. This research uses descriptive method. Data collection techniques used in this study is a recording technique. Researchers record conversations conducted between lecturers and students. This research data comes from conversations between lecturers and students of PGSD. The result of the research shows that politeness strategy applied in English language teaching especially in PGSD student of 6th semester English Course at Muhammadiyah University Tangerang is a strategy of politeness of context. The context found is the compassion of imperative speech acts in the form of forcing, inviting, and pleading with the discovery of three of the four functions of language according to Leech (1993: 162), ie competitive, convivial, and collaborative. However, the commonly used language function is the collaborative language function. The success rate of use of imperative speech acts is very effective in teaching English so that learning can be done well.
\end{abstract}

Keywords: Speech, Imperative, Teaching English

\section{A. INTRODUCTION}

\section{Background}

Language plays an important role in communication. With language, humans can interact with each other. Through language, lecturers can convey a purpose to the students, vice versa. Lecturers can give greetings, questions, praise, and orders to the students. Language activity especially in English 
teaching process is very precisely studied with the theory of speech act (speech act). Because the activity of speakimg occurs in the context of teaching. A speech event is a form of speech involving two or more parties in a particular time, place and situation (Chaer and Agustina 2004: 62). Meanwhile, according to Austin (1965), the language is not just saying something (saying some thing) but also doing something else (doing some thing), which convey certain intentions, such as sending or asking others to do something requested by speakers. Speech is a pragmatic analysis, a branch of language science that examines the language of the aspects of its use. Cohen (in Hornberger and McKay (1996) defines speech acts as a functional entity in communication, while Yule (1996) states that speech acts as an act done through speech.

\section{The Objective}

The objective of this research is to analyze Lecturer's Imperative Teaching in teaching English to PGSD students at Muhammadiyah University of Tangerang.

\section{Theoretical Framework}

Searle (1976) classifies speech acts based on the speaker's intent when speaking into five types: 1) Representative is a speech act that binds the speaker to the truth of what he says; 2) The act of speech directive is a speech act intended by the speaker so that the partner said to act according to what is mentioned in his speech; 3) The expressive speech act is a speech act intended for the speaker to be defined as an evaluation of what is mentioned in the speech, including the utterance of thanking, complaining, congratulating, flattering, praising, blaming, and criticizing; 4) Commissive speech acts are speech act which binds its speaker to carry out all the things mentioned in his utterances, eg swearing, pledging, threatening, declaring ability, vowing; 5) Declaration of speech acts is a speech act intended by the speaker to create new things (status, circumstances, etc.).

Some grammarians use other terms that are basically not much different from the term imperative sentence, such as Alisjahbana and Gorys 
Keraf using the term sentence command. Alisjahbana (1978) interpreted the phrase of command as saying that its contents ruled, coerced, ordered, invited, requested, that the ordered person do what is meant in command. Leech (1993: 162) classifies the function of illustrative speech act into four types, namely competitive, convivial, collaborative and conflictual. The meaning of the four functions of speech acts are: 1) Competitive is the objective of competing to compete with social goals such as asking, commanding, and begging; 2) The convention is an illocutional goal that coincides with social goals such as thanking, congratulating, offering, inviting, welcoming, and greeting; 3) Collaborative (collaboration) is the objective of ignoring social objectives such as announcing, instructing, and ordering, demanding, imposing, reporting; 4) Conflicting (contradictory) is the purpose of illocution contrary to social goals such as rebuking, railing, and nagging, threatening, accusing, condemning, cursing.

Research relevant to this research is research conducted by Iwan Khairi Yahya with title directive speech acts in the interaction of teaching and learning subjects Indonesian language and literature in SMA Negeri 1 Sleman Yogyakarta. The results showed that the use of question types and questioning functions were used more when compared with the use of other types of speech acts and functions. The types of speech acts found in the directive include the types of requests, questions, orders, prohibitions, permission, advice. The functions of the directive speech acts found include the functions of: requesting, pleading, praying, asking, interrogating, instructing, demanding, restricting, approving, granting, condoning, allowing, advising, advising, asking and demanding, asking and directing, inviting and praying, directing and asking, directing and Demanding, directing and advising, and the latter allowing and suggesting.

Subsequent research relevant to this research conducted by Ratni Indah Suryantini with the title of expressive speech acts on the interaction of teacher learning and grade 1 elementary school. The result of the research are: (1) expressive speech form on teacher learning interaction and 1st grade students of SD Negeri Purworejo and SD Negeri Gemolong 1 academic year 
2011/2012 number 21 expressive speech data with intent to congratulate, praise, blame and condolence, (2) ) Expressive speech strategies used in the interaction of teacher learning and 1st grade students of SD Negeri Purworejo and SD Negeri Gemolong 1 academic year 2011/2012 is a direct and indirect expressive speech strategy with news, question and command mode.

\section{Methodology}

This research is qualitative research with descriptive method. This research data is a speech in the process of learning to teach English. The entry examined is the lecturer's imperative speech. Technique used in data collection is a technique of free libat ably proficient, recording techniques and record techniques. The data is obtained directly by recording the dialog or lecturer's speech during the learning process takes place. Once data is collected, data analysis is performed. In this research, data collection method used is simak method and skill method. Methods refer to have basic techniques tangible techniques tapping (Mahsun, 2005: 90). Technique tapping is called as a basic technique in the method refer to the essence of the dye is realized by tapping. Researcher got the data done by tapping the use of language of a lecturer and student. In addition, the researchers also used the method skillfully. Method of provision of data with skill method caused by way taken in collecting data that is in the form of conversation between researcher with informant (Mahsun, 2005: 90). The skill method has the basic technique of fishing technique, because the expected conversation as the implementation of the method is only possible if the researcher gives stimulation to the informant to generate the language phenomenon that the researcher hopes. Data analysis using this pragmatic method aims to describe imperative politeness in the interaction of lecturers and students of PGSD. This method is also used as a supporting method of descriptive research used by researchers. The results of data analysis of imperative politeness research of lecturers and students are presented informally. The findings of research are in the form of imitative speech acts and the meaning of imperative speech acts. 


\section{B. RESULTS AND DISCUSSION}

The act of imperative speech is a form of speech that serves to express or demonstrate attitudes in the form of forcing, inviting, enjoining, urging, pleading, suggesting and governing with the discovery of three of the four functions of language according to Leech (1993: 162), namely competitive, convivial, and Collaborative.

Data 1: Deceive Imperative Forms Collaborative Functions

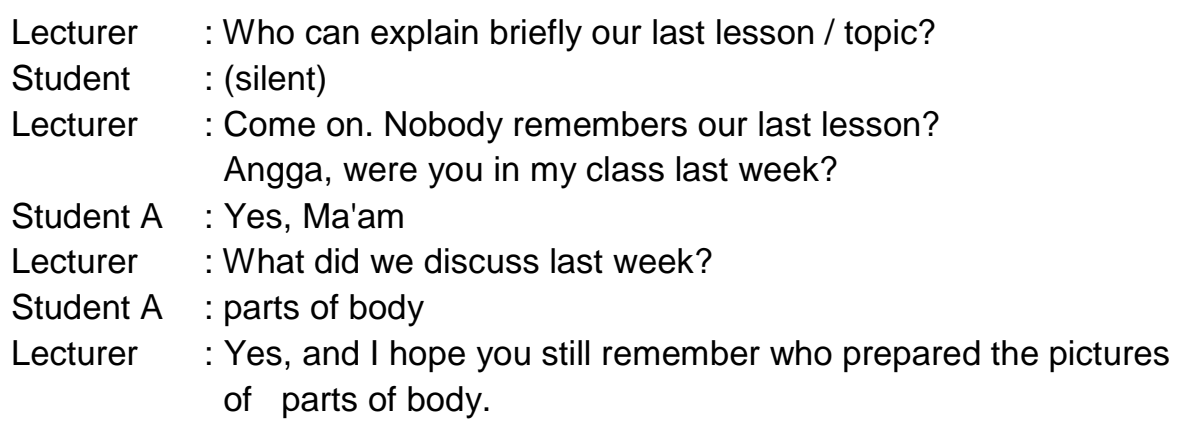

\section{Context}

When the lecturer asked about last week's lecture materials, all the students in the class were silent and no one answered. Seeing this, the lecturer immediately acted by forcing the student well with the words "come on. Nobody remembers our last lesson? ". From the form of forced speech above, the function in accordance with the speech is a collaborative function (working together) that aims to require cooperation between students and lecturers so that lectures can run smoothly.

Data 2: Imperative Imperative Tasks form invites Conventional Functions

$\begin{array}{ll}\text { Lecturer } & \text { : Now, it's time for exercise take out your exercise book. } \\ \text { Student } & \text { : Yes, ma'am. } \\ \text { Lecturer } & \begin{array}{l}\text { : Open your module and do exercise 5. This is going to be } \\ \text { group work. so please make a group of four people. }\end{array} \\ \text { Student } & : \text { yes } \\ \text { Lecturer } & \text { : Do you have a question? } \\ \text { Student A } & : \text { Should we do all questions? } \\ \text { Lecturer } & : \text { Yes. There are only five questions in the exercise. }\end{array}$




\section{Context}

When the lecturer has explained the course materials in front of the class and some students ask questions. Then, the lecturer gives the task of doing the exercises and forming the group to discuss with each group. Then the students asked to confirm the instruction of the teacher is whether the matter in doing all. Meanwhile, the purpose of group formation in doing the exercises so they can discuss, cooperate and solve problems together.

Data 3: Speech Imperative imperative forms Collaborative Functions

Lecturer : Well, students, the bell is ringing. We have to stop here.

Student : I'm not finished with the exercise.

Lecturer : ok, listen all. Those who are not finished with the exercise can not leave the class. You have to stay here and finish the exercise.

Student : How about us? We have finished.

Dosen : Those who have finished can submit your work to me and you can leave the class. See you tomorrow.

\section{Context}

When the bell rang, the lecturer asked all the students to stop their work. While there are some students still have not completed their task. While some students have already done the task before the bell rang. The lecturer asks the students who have completed the task so that the task can be gathered and they can leave the class. From the above urgent form of speech, the function associated with the utterance is a collaborative function (in collaboration). The relationship between context and function in the form of the above speech, that is, the lecturer wants the student to be able to complete the task as soon as the bell sounds and the time to finish the task is over.

\section{CONCLUSION}

Based on the results of data analysis above, can be drawn some conclusions from this article. Among these are the politeness strategies applied in teaching English, especially in the 6th semester PGSD students at Muhammadiyah University of Tangerang into a strategy of politeness of context when it is found the politeness of 
imperative speech acts in the form of force, invite, and urges with the discovery of three of the four functions of language according to Leech (1993: 162), ie competitive, convivial, and collaborative. However, the frequently used language function is a collaborative language function. The success rate of use of imperative speech acts is very effective in teaching English so that learning can be done well. 


\section{DAFTAR PUSTAKA.}

Austin, J.L. 1965. How to Do Things with Words. United States of America: Havard University Press.

Chaer, Abdul dan Agustina. 2004. Sosiolinguistik Perkenalan Awal. Jakarta: PT. Rineka Cipta.

Cohen, A.D. (1996). Dalam N. H. Hornberger \& S. L. McKay. Sociolinguistics and Language Teaching. Cambridge: CUP

Leech, Geoffrey. 1993. Prinsip-Prinsip Pragmatik. Jakarta: Universitas Indonesia.

Lavinson, SC. 1994. Pragmatics. Cambridge: Cambridge University Press

Mahsun. 2005. Metode Penelitian Bahasa: Tahapan, Strategi, Metode, dan Tekniknya. Jakarta: PT Raja Grafindo Persada.

Searle, J.R. 1976. A Classification of Illocutionary Acts dalam Language in Society

5. Great Britain: University of California.

Wijana, I Dewa Putu. 1996. Dasar-Dasar Pragmatik. Yogyakarta: Andi.

Yule, George. 1996. Pragmatics. Oxford: Oxford University Press 